\title{
Психологічні особливості розвитку децентрації в сучасних умовах
}

\begin{abstract}
Анотація. У статті систематизовані основні наукові погляди вітчизняних та зарубіжних психологів різних шкіл і напрямків на проблему розвитку децентрації. Децентрацію визначено як провідний шлях подолання егоцентризму, інтегральну властивість особистості, що відображає здатність людини змінювати власну позицію, координувати різні точки зору. Розглянуті психологічні особливості, чинники децентраџї та фактори, що можуть сприяти ї̈ затримки. Доведено, що децентрачія в основному залежить від зовнішніх умов розвитку індивіда й найбільш активно розвивається у дитячій сюжетно-рольовій грі. Заміна традиційної рольової гри комп'ютерним сурогатом затримує розвиток децентраиї̈ у сучасних дітей.
\end{abstract}

Ключові слова: децентрачія, егочентризм дитини, координачія точок зору, спілкування.

Засадничою потребою сучасності є необхідність у гуманізації суспільства, яка вимагає нового типу взаємин між людьми, формування стосунків, побудованих на взаємоповазі, умінні побачити світ очима іншої людини. Вже у дошкільному віці дитина повинна уміти узгоджувати свої дії з партнерами по спільній діяльності, відчувати межі прийнятної активності та дистанції, самостійно встановлювати i підтримувати ділові та особисті контакти 3 однолітками та дорослими, приймати думку та позицію іншого, поважати чужий вибір, вміти розв'язувати конфліктні ситуації, реально оцінювати ставлення інших людей до себе та свій статус у групі однолітків. Важливим компонентом реального бачення себе у світі, об'єктивного сприймання дійсності, взаєморозуміння 3 оточуючими виступає рівень розвитку децентрації дитини.

Розвиток децентрації залежить від дозрівання біологічних структур індивіда (за Ж. Піаже), а також від специфіки навчання й виховання, особливостей життєдіяльності, в яких у суб' єкта виробляються навички спілкування й соціально-психологічної компетентності, тобто від зовнішніх умов середовища. I якщо фізіологічні закони, як і раніше, залишаються приблизно сталими, то зовнішні умови кардинальним чином змінилися (Н.М. Верцинська, 3. Г. Зайцева, Л. О. Кондратенко, О. І. Коче- тов). I найбільших змін зазнало середовище, у якому розвивається дитина.

Комп'ютери входять в нові області людської практики, змінюючи при цьому не тільки окремі дії, але й людську діяльність взагалі. Сучасні багатовимірні комп'ютерні ігри здатні змінювати уявлення дитини про себе й навколишній світ. Віртуальна реальність, яка формує віртуальний «світ» комп'ютерної гри, сприймається гравцем як повноцінна реальність, оскільки з'являється ефект «присутності». I коли діти залучаються до віртуального світу у дошкільному або молодшому шкільному віці, то комп'ютерні ігри частково, а в деяких випадках навіть повністю, витісняють із їнього життя традиційну рольову гру. Але ж саме рольова гра є середовищем, де здобуваються навички взаємодії з оточуючими людьми, де дитина одержує вербальний і невербальний зворотній зв'язок для узгодження своєї думки з думкою інших учасників гри, без чого не відбувається, або уповільнюється процес децентрації, такий необхідний для повноцінного спілкування дитини.

Розробка проблеми децентрації тісно пов'язана 3 дослідженнями пізнавального егоцентризму (Л.С. Виготський, П.Я. Гальперін, М. Дональдсон, Д.Б. Ельконін, Г.С. Костюк, С.Д. Максименко, Н.О. Мiзіна, В.О. Недоспасова, Л.Ф. Обухова, Ж. Піаже, А.-Н. Перре-Клермон, Дж. Сме- 
дслунд, Дж. Флейвел, Г.А. Цукерман та ін.), особливостей спілкування й діяльності особистості (К.О. Абульханова-Славська, Б.Г. Ананьєв, М.Й. Боришевський, Н.Д. Володарська, С.В. Гейко, Д.Б. Ельконін, О.В. Запорожець, I. М. Коган, О.М. Леонтьєв, О. Р. Лурія, Т. І. Пашукова, Н.І. Пов’якель, О.В. Проскура, С.Л. Рубінштейн, О.В. Соломатіна, Н.В. Чепелєва, та ін.), міжособистісних стосунків (Г.М. Андрєєва, К. О. Абульханова-Славська, Л.П. Журавльова, В. Р. Кісловська, Я. Л. Коломинський, М. І. Лисіна, В. С. Мухіна, Т. О. Рєпіна, О. О. Смірнова).

Проблема егоцентризму досліджується і в сучасній українській психологопедагогічній науці (А. М. Богуш, I. В. Вєтров, С.Й. Гаваші, Є.В. Гейко, Т.Є. Гура, О.Б. Мельничук, І.Г. Цемрюк, Н. Ф. Шевченко). Обговорюючи у своїх роботах проблеми подолання егоцентризму сучасні дослідники майже одностайно сходяться на тому, що вікові рамки етапів розвитку децентрації є досить розмитими, не до кінця вивчені причини затримки децентрації, у науковій літературі немає чіткого визначення умов розвитку децентрації.

Розвиток децентрації - це складний багатоаспектний процес, нормальне протікання якого відбувається в умовах, коли дитині надана можливість:

- розвинути просторове мислення, оволодіти предметним світом, зрозуміти своє місце в просторі та часі;

- зрозуміти закономірності і розвинути здатності соціальної взаємодії;

- усвідомити свій особистісний статус; навчитися виражати своє емоційне ставлення до навколишнього, 3 перенесенням знань, сформованих щодо іншої людини, на себе; в міру розвитку інтелекту й свідомості навчитися емпатийній здатності до засвоєння чужої точки зору й оцінок оточуючих.

Зупинимось на цих природних умовах розвитку децентрації дещо докладніше.

Необхідною умовою для подолання егоцентризму, умовою успішного пізнання i активного перетворення дійсності є вмін- ня орієнтуватись у просторі. Становлення просторової децентрації проходить завдяки діяльності з матеріальними предметами в умовах реального просторово-часового континууму. Вільне оперування просторовими образами $є$ тим фундаментальним вмінням, яке об'єднує різні види навчальної і трудової діяльності, взагалі важко визначити хоча б одну галузь діяльності людини, де вміння орієнтуватися в просторі не відігравало б істотної ролі.

У формуванні просторових уявлень і способів орієнтації в просторі беруть участь різні аналізатори (кінестетичний, дотиковий, зоровий, слуховий, нюховий). У маленьких дітей особлива роль належить кінестетичному, дотиковому і зоровому аналізаторам.

Просторове орієнтування здійснюється на основі безпосереднього сприймання простору і словесного позначення просторових категорій (місця розташування, віддаленості, просторових відносин між предметами). У поняття «просторова орієнтація» входить оцінка відстаней, розмірів, форми, взаємного розташування предметів та їх положення стосовно того, хто орієнтується.

У більш вузькому значенні вираз «просторова орієнтація» це орієнтування на місцевості. У цьому сенсі під орієнтуванням у просторі мислиться: а) визначення місцезнаходження суб'єкта по відношенню до оточуючих його об'єктів; б) визначення місцезнаходження об'єкта відносно людини, що орієнтується в просторі; в) визначення просторового розташування предметів один до одного, тобто просторових відносин між ними. Аналізуючи психологічні особливості освоєння простору дітьми, С. Л. Рубінштейн писав: «Процес оволодіння простором відбувається у дитини в тісній єдності дії і пізнання. Дитина пізнає простір у міру того, як вона його опановує» [8, с. 271]. Важливе значення С. Л. Рубінштейн надавав емоційній забарвленості в сприйнятті дитиною простору. У цікавих для дитини предметах вона здатна виділити безліч деталей, правда, не завжди істотних. Разом з тим, початкове 
сприйняття простору дітьми характеризується схематичністю і рядоположеністю, тобто егоцентричністю, слабкістю аналізу та синтезу.

Орієнтування дитини в просторі дозволяє їй освоїти вміння переносити свою, спочатку фіксовану точку відліку в будьяку іншу точку простору i переводити, «трансформувати» всі просторові відносини з однісї системи відліку до іншої.

Стрижнем загального розвитку розуміння простору $є$ перехід від фіксованої на собі системи відліку (координат) до системи з вільно переміщуваною точкою відліку» [8, с. 272]. У дошкільному віці дитина освоює словесну систему відліку по основним просторовим напрямках: вперед-назад, вгору-вниз, праворуч-ліворуч. У період шкільного навчання діти опановують нову систему відліку - сторони горизонту (північ, південь, захід, схід). Причому освоєння кожної наступної системи відліку базується на міцному знанні попередньої.

Активний розвиток сприймання в ранньому віці, оволодіння діями з реальними предметами дозволяють дитині достатньо точно визначати форму, колір, величину предметів, їх положення в просторі в тих випадках, коли це необхідно для виконання певної доступної їй дії.

Істотну роль у пізнанні простору відіграє фактор формування імпліцитного (невираженого, який мається на увазі) уявлення про простір, свого роду несвідома впевненість в існуванні і стабільності навколишнього предметного світу і суб' єктивне «вписування» себе в цей світ [10]. Це явище точно охарактеризував М.О. Бернштейн: «Коли ми ходимо, піднімаємося сходами, обертаємося навколо себе, ми не тільки знаємо, а й відчуваємо з усією наочністю і безпосередністю, що переміщаємося $м и$, в той час як простір 3 предметами, що його наповнюють залишається нерухомим, хоча і всі рецептори говорять нам протилежне. Якщо можна так висловитися, кожен суб'єкт ще з раннього дитинства долає для себе егоцентричну, птоломеєвську систему світосприйняття, замінюючи їі коперниканською» [3, с. 82].
Але його ствердження, що абсолютно точно передає ситуацію у реальному світі, виявляється хибним у комп'ютерному віртуальному світі, у якому все відбувається навпаки - світ обертається навколо людини, яка залишається нерухомою, створюючи ілюзію руху.

Як вже говорилось вище, діти до певного віку не вміють розрізняти суб'єктивний і зовнішній світ. Дитина починає з того, що ототожнює свої уявлення з речами об'єктивного світу, і лише поступово вчиться ïx розрізняти. Цю закономірність, згідно Ж. Піаже, можна застосовувати як до змісту понять так і до найпростіших сприйняттів.

Отже, перші кроки на шляху від егоцентризму до децентрації дитина робить освоюючи простір, пізнаючи реальні предмети, маніпулюючи ними, опановуючи власне тіло і використовуючи його як систему координат. Вона проходить шлях від уявного до реального бачення, усвідомлюючи наявність стабільного навколишнього предметного світу i «вписуючи» себе в цей світ.

Наступним кроком після того, як дитина засвоїла, що матеріальний світ існує поза нею, від неї не залежить і їй не підпорядковується, стає диференціація від людського світу - соціуму. Таки вчені, як В.О. Недоспасова, Д.Б. Ельконін, М. Дональдсон, Л.Ф. Обухова та ін. наголошують на тому, що: зникнення феноменів егоцентризму у дитини відбувається за наявністю двох умов - при орієнтуванні дитини на ставлення до інших осіб і при урахуванні власного місця в ситуації.

Важливою умовою розвитку децентрації є реальна взаємодія $з$ реально існуючими, незалежними від дитини іншими представниками соціуму. Коли ж в оточенні дитини штучно створюється атмосфера повної центрації на дитині, то розвиток децентрації значно сповільнюється.

За даними Е. Г. Ейдеміллера і В.В. Юстіцкіса егоцентризм може залежати від тактики сімейного виховання, особливостей сімейних взаємостосунків, пов'язаних 
з повнотою родини, їі благополуччям або неблагополуччям [13].

Враховуючи прийняту у віковій психології класифікацію тактик сімейного виховання (диктат, опіка, невтручання і співробітництво) і не зупиняючись докладно на кожній, відзначимо, що багато вчених (В.В. Абраменкова, А.В. Петровський, Т. І. Пашукова, Е. Г. Ейдеміллер, В.В.Юстіцкіс і ін.) вважають тактику співпраці найбільш прийнятною для подолання егоцентризму.

Н.Ю. Плотнікова виявила зв'язок між рівнем розвитку децентрації в дитини i тим, наскільки мати здатна прийняти відмінність точки зору дитини від власної. Так, якщо в родині $є$ порушення міжособистісної комунікації (у першу чергу материнська депривація), то в дитини виявляється досить низький рівень розвитку децентрації, незважаючи навіть на високі показники інтелектуального розвитку. Чим більш довірливі і відкриті стосунки панують у родині, тим у дитини є більше можливостей для психологічного відділення від матері, а тим самим і для розвитку здатності до орієнтації на іншого, уміння ставати на точку зору іншої людини [6].

T. I. Пашукова, вивчаючи егоцентризм підлітків зауважує: у неблагополучних родинах егоцентризм у дітей більший, ніж у благополучних. У неблагополучних родинах, де має місце сімейна депривація, его-система дитини зазнає руйнівних впливів. У дітей з'являється потреба в протидії руйнуванню, у стабілізації его-стану, яку й реалізує егоцентризм, підсилюючи особистісну напруженість [5, с. 199].

На рівень егоцентризму дітей істотний впливає й стиль класного керівництва. Вчителі з демократичним стилем керівництва, на відміну від педагогів практикуючих авторитарний стиль, орієнтовані на учнів, на діалог 3 ними, що впливає на рівень егоцентризму учнів. При демократичних стосунках 3 вчителем, его-система учнів зазнає менше навантаження і прояв егоцентризму зменшується [5].

M.І. Алексєєва пов'язує егоцентричність молодших школярів 3 навчальною діяльністю взагалі, яка, на відміну від ігрової, знижує рівень співчуття, змушуючи дитину зосереджуватися головним чином на власних навчальних інтересах i проблемах (тут доречна аналогія 3 комп'ютерними іграми, де гравець один проти всіх). Внаслідок цього, вважає вчена, молодший школяр - це морально не співчуваюча (егоцентрична) особистість [1].

Отже, найбільш сприятливим середовищем для визрівання децентрованої позиції, $\epsilon$ середовище, де его-система дитини звільнена від тиску і навантажень. Д.Б. Ельконін таким середовищем вважає сюжетно - рольову гру, основним змістом якої $є$ норми людських стосунків. Гра виступає не тільки як реальна практика зміни позиції при прийнятті на себе ролі, але і як практика стосунків 3 партнером по грі 3 погляду тієї ролі, яку виконує партнер; не тільки як реальна практика дій із предметами відповідно до наданих їм значень, але і як практика координації точок зору на значення цих предметів без безпосереднього маніпулювання ними [14].

Рольова гра стає для дитини способом освоєння моральних норм. Лише у рольовій грі дитина отримує навички соціальної взаємодії, в цій взаємодії, в переходах «Я — я-в-ролі» і узгодженні «моя роль роль партнера» відбувається пізнавальна i емоційна децентрація. Рольова гра, в якій здійснюється систематичне «розхитування» уявлень людини про абсолютність свого становища у світі речей і людей, і $є$ механізмом децентрації особистості.

Саме гра, виступає кооперативною діяльністю дітей і є засобом розвитку процесу децентрації. Але індивідуальна гра, в якій у дитини немає необхідності ні в зміні позицій, ні в координації своєї точки зору 3 точками зору інших учасників (наприклад, коли партнером у цій грі виступає комп'ютер), може навпаки стимулювати егоцентричність дитини.

В житті ставлення до іншої людині виявляється насамперед у діях, спрямованих на неї, у тому числі у спілкуванні. Психологи Г.М. Андреєва, К. О. Абульханова-Славськая, М. І. Лисіна, Т. О. Рєпіна, 
Я.Л. Коломинський та ін. розглядають стосунки як внутрішню психологічну основу спілкування і взаємодії людей. Спілкування виступає як особлива комунікативна діяльність, спрямована на формування взаємостосунків. Тому від рівня розвитку децентрації багато в чому залежить успішність міжособистісних стосунків. Адже саме децентрація пов'язана 3 виконанням функцій координації й урахування точок зору учасників міжособистісної взаємодії.

Розвиток навичок урахування точок зору інших людей здійснюється під час взаємодії дітей з іншими дітьми та дорослими. Ці навички формуються на основі операції оборотності, а децентрація стає механізмом переключення уваги дитини зі своєї точки зору або перспективи на інші можливі. Децентрована, позиційна дія розвивається лише в умовах спеціального формування позиції, які організуються дорослим не як технічна вправа, а як послідовне вибудовування стосунків, необхідних для того, щоб з'явився внутрішній оцінювач ситуації [14].

У психологічній літературі представлено два види взаємодії: кооперація і конкуренція. Кооперація або кооперативна взаємодія, означає координацію одиничних сил учасників. Засобом координації виступають стосунки, які реалізовані, насамперед, у кооперації (по О. М. Леонтьєву) [4].

Інший тип взаємодії - конкуренція, найбільше яскраво представлений у формі комунікативного конфлікту. Важливу роль комунікативним конфліктам відводив Дж. Смедслунд. Він підтвердив гіпотезу Ж. Піаже, про те, що саме завдяки конфліктам діти починають розуміти відносність своїх позицій і співвідносити їх з точками зору інших людей [16]. У такому випадку конфлікт сприяє формуванню всебічного розуміння проблеми, а також мотивації партнера, що займає іншу точку зору. Сам факт іншої аргументації, визнання її законності сприяє розвитку елементів кооперативної взаємодії усередині конфлікту, і як наслідок - децентрації.

А.-Н. Перре-Клермон розглядала конфлікт як детермінуючий фактор розвит- ку в соціальній взаємодії. Саме конфлікт, на думку дослідниці, змушує дитину координувати свої дії з діями інших і тим самим залучає її до процесу децентрації [7]. Як бачимо, розвиток децентрації найбільш ефективний в ситуації взаємодії, яка викликає конфлікт точок зору та необхідність їх узгодження.

Одним із важливих показників розвитку децентрації дитини є розуміння нею умовностей мови: переносного змісту метафор, прислів'їв, байок, а також «підтексту» творів. Розуміння умовності є своєрідним інтегрованим показником загального інтелектуального розвитку дитини, що відображає вміння міркувати, аналізувати, співставляти, а також виявляе афективноемоційні особливості дитини [9].

Швидкість протікання децентрації дитини безпосередньо пов'язана з розвитком іiі уяви. Завдяки уяві у людини формується важлива для спілкування здатність уявляти себе на місці іншого. При цьому децентрацію можна розглядати як базовий механізм рефлексії, ідентифікації та емпатії [5]. Децентрація, рефлексія та емпатія виконують функції узгодження взаємостосунків суб'єктів діяльності і спілкування.

Г.М. Андреєва вважає, що ідентифікація має місце, коли припущення про внутрішній стан партнера будується на основі спроби поставити себе на його місце. Емпатія «є афективне розуміння. Емоційна їі природа проявляється саме в тому, що ситуація іншої людини, партнера по спілкуванню, не стільки «продумується», скільки «відчувається» [2, с. 144].

Рефлексія виступає у формі усвідомлення діючим суб' єктом того, як він у дійсності сприймається й оцінюється іншими індивідами. Рефлексія — це не просто знання або розуміння суб' єктом самого себе, але й з'ясування того, як інші знають і розуміють «рефлексуючого», його особистісні особливості, емоційні реакції й когнітивні (пов'язані з пізнанням) уявлення.

Емпатія відкриває рефлексивні здатності дитини проникати своїми почуттями й розумом у стан іншої людини, передбачити можливу їі поведінку, виявляти моральну й 
реальну підтримку, що сприяє децентрації особистості дитини.

Процес розвитку децентрації багато в чому залежить і від спрямованості особистості.

Децентрована спрямованість характеризується скерованістю людини на пізнання навколишнього світу. Вихідним моментом для розвитку даної скерованості особистості є синтез різних поглядів на ситуацію, включаючи і власний погляд людини (М. Феффер) [15]. Під егоцентричною спрямованістю особистості розуміється спрямованість людини на саму себе, свій внутрішній світ [12].

Значить, ефективна міжособистісна взаємодія, заснована на розумінні партнерами один одного, перебуває в прямої залежності від децентрації і сама є ефективним засобом її розвитку.

Тому ми вважаємо, що розвиток децентрації найбільш залежить від зовнішнього середовища, зміна якого не може не призводити до зміни механізмів децентрації, описаних Ж. Піаже, Дж. Смедслундом, М. Феффер.

Отже, підсумовуючи розглянуті вище наукові теорії, що пояснюють класичний перебіг розвитку децентрації у дитини, ми можемо зробити наступні висновки:
- егоцентризм є необхідним щаблем розвитку дитини, який виступає певною формою захисту мотивованою страхом перед зовнішнім світом;

- вміння орієнтуватися в просторі необхідна умова для подолання егоцентризму;

- тактика сімейного виховання, стиль педагогічного керівництва, міжособистісні стосунки дітей суттєво відбиваються на характері розвитку особистості і обумовлюють іiі егоцентровану або децентровану спрямованість;

- децентрація найбільше активно розвивається у дитячій сюжетно-рольовій грі;

- децентрація є базовим механізмом рефлексії, ідентифікації та емпатії;

- децентрація виступає інтегративною властивістю, від рівня розвитку якої залежить успішність взаємодії людей в процесі міжособистісного спілкування і яка є антиподом егоцентричності - фіксованості людини на своїй позиції, думці, уявленні, соціальній ролі тощо.

I хоча проблема егоцентризму й децентрації не втрачає актуальності та є предметом вивчення протягом багатьох років, крапка в її дослідженні дотепер не поставлена.

\section{Список використаних джерел:}

1. Алексєєва М. І. Психологія ранньої юності / М. І. Алексєєва. - К. : Знання УРСР, 1971. $-48 \mathrm{c}$.

2. Андреева Г.М. Социальная психология / Г.М. Андреева - М. : Из-во Моск. универ., 1990. - $416 \mathrm{c}$.

3. Бернштейн Н. А. О построении движений / Н. А. Бернштейн. - М. : Медгиз, 1947. $254 \mathrm{c}$.

4. Леонтьев А.Н. Избранные психологические произведения : в 2-х т. / А.Н. Леонтьев. М. : Педагогика, 1983. - Т. 2. - 320 с.

5. Пашукова Т.И. Эгоцентризм: феноменология, закономерности формирования и коррекции / Т.И. Пашукова. - Кировоград : Центрально-Украинское издательство, 2001. $-338 \mathrm{c}$.

6. Плотникова Н. Ю. Взгляд на становление личностной позиции школьника в контексте детско-родительских отношений : дайджест / Н. Ю. Плотникова // Психология обучения. - 2009. - № 4. - C. 124-125.

7. Перре-Клермон А.-Н. Роль социальных взаимодействий в развитии интеллекта детей / А.-Н. Перре-Клермон ; пер. с фран. - М. : Педагогика, 1991. — 249 с.

8. Рубинштейн С. Л. Основы общей психологи : в 2-х томах / С. Л. Рубинштейн. - М. : Педагогика, 1989. - Т. 1. - 486 с.

9. Семаго Н.Я. Теория и практика оценки психического развития ребенка. Дошкольный и младший школьный возраст / Н. Семаго, М. Семаго. — СПб. : Речь, 2010. — 384 с. 
10. Столин В.В. Самосознание личности / В.В. Столин. - М. : Издательство Московского Университета, 1983. - $284 \mathrm{c.}$

11. Чекстере О.Ю. Захоплення комп’ютерними іграми як фактор впливу на процес децентрації у дітей / Оксана Чекстере // Актуальні проблеми психології: Психологічна теорія і технологія навчання / за ред. С. Д. Максименка, М. Л. Смульсон. - К. : ДП «Інформ.аналіт. агентство», 2010. - Т. 8, вип. 7. - С. 268-279.

12. Шрёдер Х. К дифференциально-психологическому изучению социальной децентрации / Х.К. Шрёдер // Психологические состояния. Экспериментальная и прикладная психология. - Л. : Изд-во Ленинград. ун-та, 1981. - Вып. 10. — С. 125-131.

13. Эйдемиллер Э.Г. Психология и психотерапия семьи / Э. Г. Эйдемиллер, В. В. Юстицкис. - СПб. : Питер, 1999. - 656 с.

14. Эльконин Д.Б. Избранные психологические труды / Д. Б. Эльконин. - М. : Педагогика, 1989. $-534 \mathrm{c}$

15. Feffer M. Cognitive Aspect of Role-Taking in Children / M. Feffer, V. Gourevitch // Jornal of Personality and Social Psychology, 1966. - Vol. 14. - P. 415-422.

16. Smedslund J. Piagetian Psychology in practice / J. Smedslund // British Jornal of Educational Psychology. - 1978. - Vol. 47. - Part. 1. - P. 3-9.

Аннотация. В статье систематизированы основные научные взгляды отечественных и зарубежных психологов разных школ и направлений на проблему развития дещентрации. Децентрачия определяется как основной путь преодоления эгоцентризма, интегральное свойство личности, которое отражает способность человека изменять свою позицию, координировать различные точки зрения. Рассмотрены психологические особенности, факторы децентрации и причины, способствующие ее задержки. Доказано, что децентрация в основном зависит от внешних условий развития индивида и наиболее активно развивается в детской сюжетно-ролевой игре. Замена традиционной ролевой игры компьютерным суррогатом задерживает развитие децентрации у современных детей.

Ключевые слова: децентрачия, эгоцентризм ребенка, координация точек зрения, общение.

Abstracts. In the article the basic scientific views of domestic and foreign psychologists different schools and directions of the problem of decentration. Decentration identified as leading the way to overcome self-centeredness, integral property of the individual, reflecting the person's ability to change its position to coordinate the different points of view. Considered the psychological characteristics of decentration and factors that may contribute to its delay. It is proved that decentration depend on external conditions of the individual and the most actively developing in children's game. Replacement of traditional role-playing game on a computer retards the development of substitute decentration in today's children.

Keywords: decentration, childish egocentrism, coordination perspectives, communication. 